\title{
MUSA, REFUGIO Y PESADILLA DE POETAS: LA GRAN CIUDAD EN LA DÉCADA EXPRESIONISTA ALEMANA
}

\author{
Pascual Riesco Chueca \\ (Universidad de Sevilla) \\ riescochueca@us.es
}

\begin{abstract}
RESUMEN: Ignorada por la poesía esteticista de entre siglos, la gran ciudad irrumpe como tema literario para la lengua alemana hacia 1910. Berlín y Viena, grandes babilonias de placer y apocalipsis, nutren una riquísima producción. Ante los insólitos paisajes de la tecnología y la masificación, se exploran nuevos estilos, en particular, los ritmos sincopados y la yuxtaposición de imágenes atrevidas e inesperadas, a modo de collage. En estas páginas se ofrece una selección traducida de siete autores de la etapa expresionista, escogidos entre los menos familiares para el público español (Boldt, Van Hoddis, Zech, Lotz, Wegner, Petzold y Lichtenstein); en su práctica totalidad se trata de poemas no traducidos previamente al castellano.
\end{abstract}

PALABRAS CLAVE: gran ciudad, expresionismo alemán, paisaje, traducción.

\section{POETS' MUSE, SHELTER AND NIGHTMARE: THE BIG CITY AND THE GERMAN EXPRESSIONIST DECADE}

ABSTRACT: Ignored by the aestheticist poets of the turn of the century, the great city suddenly grows into a literary theme in Germany around 1910. Berlin and Vienna, great Babylonian metropoles of pleasure and apocalypse, deliver an overwhelming production. Against the backdrop of unprecedented landscapes, built out of technology and overcrowding, new styles are explored, in particular, the syncopated rhythms and the juxtaposition of daring and unexpected collage-like images. In the following we offer a translated selection of authors from the expressionist years, chosen from among the least familiar to the Spanish public (Boldt, Van Hoddis, Zech, Lotz, Wegner, Petzold and Lichtenstein). Nearly all the poems included have no previous translation into Spanish.

KEYWORDS: big city, German expressionism, landscape, translation.

Para un país de dominante rural como Alemania, con tantas pequeñas ciudades dispersas y cortes provincianas, con tantos poetas oriundos de la profunda Prusia, la aparición de la gran ciudad hubo de ser un suceso abrumador. La brusca expansión capitalista del Gründerzeit, tras la unificación imperial en 1871, precipita los cambios: industrialización, explotación minera, ferrocarril. Grandes fortunas se edifican y las ciudades se extienden con economía dual - villas de ricos comerciantes e industriales, espesos barrios obreros-. Berlín, insólita ciudad, destaca por sus rasgos diferenciales: llegada de los hugonotes tras 1685, rescoldos eslavos y afanes cosmopolitas, rápido crecimiento durante el siglo XIX, capital del imperio. La metrópolis, que llega a ser la más poblada del continente hacia 1920, adquiere la dimensión de mito viviente, prodigioso teatro de asombros y modernidades. Nuevo ámbito moldeador de 
sensibilidades, se convierte en la década de 1910-1920 en sede principal del expresionismo. ${ }^{1}$ Papel similar juega Viena, crisol de lenguas y letras, primoroso laboratorio de música y artes plásticas, como Berlín magnetizada por las aportaciones eslavas y judías.

La poesía alemana de gran ciudad es de eclosión más tardía que la francesa. Ha de esperarse al naturalismo y su intensa impregnación social. En ello se separa del temprano esteticismo del país vecino, donde Baudelaire, y luego los simbolistas, explotan el escenario urbano por sus valores formales intrínsecos. ${ }^{2}$ En lengua alemana, tras el naturalismo, grandes figuras como Hofmannsthal, Rilke y George vuelven la espalda a la metrópolis contemporánea. En efecto, el posnaturalismo no incluye entre sus temas el elenco de crudezas y tinieblas que acompañaron el despertar industrial alemán; las nuevas corrientes - diversamente encuadradas como impresionismo, fin de siècle, simbolismo, neorromanticismo, Jugendstil, esteticismo- se refugian en sus mundos ajardinados, exquisitos y decadentes. Solo con el expresionismo se asiste a una extraordinaria floración del tema de la gran ciudad (Rothe, 1981: 11-13; Becker, 1993: 58-59), lo que le valió a sus textos el término de oprobio «Asphalt-literatur». ${ }^{3}$

La ciudad expresionista no tiene por sujeto a la masa proletaria, sino al yo desperdigado del poeta. Si emerge un plural se insertará en el vago colectivo de un nosotros: noctámbulos y artistas. Lo urbano es tratado como un síntoma, sin rigores descriptivos, desdibujándose tras la rápida sucesión de sensaciones que cabriolean sobre un mapa de nerviosismo e inminencia. Frente al electrizante ámbito urbano y su rica panoplia de cafés, teatros, revistas y talleres, se registran reacciones visionarias, apocalípticas (Zawodny, 1999), se ensayan poses y provocaciones, se descubre con fruición lo grotesco y el juego onírico. El vitalismo y la prisa se convierten en valores centrales, que descubren en la ciudad un agente vigoroso y cómplice. Los nervios tensados de los habitantes de la ciudad se acoplan a los chirridos de tranvías, los petardeos del automóvil, los fogonazos de la nueva iluminación publicitaria, los planos en sucesión del cinematógrafo. ${ }^{4}$

En este hábitat, donde la técnica empieza por primera vez a fraguar paisajes, la acción humana se vuelve furtiva, confusa y descabezada, casi secundaria frente a las pulsiones de la gigantesca urbe. La conciencia de pertenecer a un mundo nuevo, lleno de peligros y aventuras, es a la vez extenuante y exaltante, sin que falten vislumbres de presuntuosa afectación urbanita, la fatuidad del superviviente en la cresta de la ola, curtido en trances y guiños. No obstante, comparado con el monigote electrizado del expresionismo, el flâneur de la tradición urbana francesa es un gran esteta humanista, anónimo pero plenamente capacitado para observar y saborear, un sujeto que administra

\footnotetext{
${ }^{1}$ Kähler (1986) revisa los perfiles de la literatura berlinesa durante la república de Weimar.

${ }^{2}$ Versluys (1987) ofrece una visión panorámica y comparativa de la poesía urbana europea y estadounidense entre 1800 y 1930.

${ }^{3}$ Recibió temprana atención de la crítica, como evidencia el libro de Rudolf Zinecker (1934) sobre poesía urbana de gran ciudad, ceñido a las décadas entre 1910 y 1930.

${ }^{4}$ Sobre la presencia literaria de la técnica en los comienzos del movimiento moderno, véase Korber (1998); acerca de la experiencia del ruido en la cultura de la gran ciudad, Payer (2018).
} 
con plena soberanía sus pasos por el bulevar. ${ }^{5}$ No así en el expresionismo, donde la mirada a la ciudad se hace desde los intersticios, o en un régimen de inversión y zarandeo que impide al paseante la vertical contemplación y la composición de cuadros sedimentados. Y tampoco se encontrará en estos poemas la representación de las masas urbanas como motor de la historia, ni cabalgará la épica proletaria sobre barricadas y banderas rojas. Ni hombre-masa ni dandi, el habitante de ciudad en el expresionismo es un ente visionario, un fluido electrizado por los potentes mecanismos de la vida urbana.

La selección presentada en estas páginas, ${ }^{6}$ que ha prescindido de figuras mayores como Trakl, Heym, Stadler y Benn, muestra un caudal principal expresionista, al que se añaden ecos naturalistas y maneras que, a pesar de la vigorosa reacción antiesteticista en las inmediaciones de la Gran Guerra, dan continuidad a las grandes voces del decadentismo.

\section{PAUL BOLDT (1885-1921)}

Hijo de un terrateniente prusiano, nace en Christfelde, la actual Chrystkowo en Polonia. Estudia filología en Múnich, Marburgo y Berlín. Atraído por la capital, cosecha éxitos tempranos por sus poesías publicadas en Die Aktion a partir de 1912. Más frecuentador de la vida crápula berlinesa que de sus círculos literarios, logra zafarse de la guerra, aduciendo una confusión mental que sus impagables poemas obligan a desmentir. En su visión de la ciudad, sensual y dinámica, predominan las notas vitalistas, que lo distancian del dramatismo apocalíptico de otros expresionistas. Tras sus éxitos iniciales, cae en el olvido, siendo redescubierto a partir de los 50. Fallece en Friburgo de Brisgovia, con 35 años.

\section{BERLÍN $^{7}$}

Los gritos de coches, como cornos de caza, repueblan de bosque gargantas de calles.

Disparos de luz. Y al unísono

los cielos arden sobre Berlín.

\footnotetext{
${ }^{5}$ Neumeyer (1999) trata de forma monográfica el concepto del flâneur, ingrediente central de una nueva sensibilidad.

${ }^{6}$ Las traducciones, que renuncian a reproducir el esquema métrico original, son del autor. Hasta donde se ha podido rastrear, los poemas escogidos carecen de previa traducción al español, con la excepción de «Josty» (Paul Boldt), del que Montserrat Armas (2016) ofreció una atinada versión. En su mayoría, los poemas de la muestra pertenecen a la llamada década expresionista (1910-1920), lo que ciertamente no garantiza que su estilo exprese los rasgos característicos del movimiento. Las traducciones presentan una medida de versos variable, que se aleja del cuidado isosilabismo de la mayoría de los originales en alemán. La estructura elegida permite el cotejo de contenidos verso a verso, y por lo tanto facilita la lectura comparada en las dos lenguas, pues salvo excepción las líneas se delimitan respetando el texto de partida. Para bien o para mal, el resultado queda confiado al oído del traductor, que ha sopesado equilibrios, simetrías y sucesiones fónicas de su agrado.
}

${ }^{7}$ Recogido en Jünge Pferde! (Boldt, 1914: 17). Traducción al inglés: Ruleman (2016). 
El Spree, con un rostro que parece el día, fulge hacia el mar buscando quien lo salve, con el sabor en los labios de la bravía ciudad y trenes crepitantes sobre sus aguas reptando.

La noche azul fluye a las florestas.

Ella sabe, deslumbrada, que estás viva.

De la espesura embisten los expresos.

El blanco atardecer que tú hilas

siente, florece, se deshoja en el todo.

Atrapas la desvaída bola terrestre

asiéndola con una mano humana

como lumbre tenaz; y así pervives.

Quién sabe en qué mundos brillaron tus acorazados ojos de astro, pétrea ciudad florida de mástiles de acero, alba flor de la tierra, oh Berlín. ${ }^{8}$

Este hermoso himno, cuyo fervor es refrenado por la ordenada segmentación en estrofas, proyecta el ajetreo y la anécdota capitalina hacia magnas fusiones panteístas. El paisaje urbano remite a la selva germánica, y su dinamismo intranquilo es el de un nervioso lance de caza, con cornos y disparos. La floresta primitiva se confunde con la ciudad, una espesura por la que avanzan los trenes expresos como jabalíes emboscados. No hay angustia expresionista, sino un implícito disfrute de la velocidad y la rica acción urbana, que trae a la memoria los entusiasmos futuristas.

Muy importante es la luminotecnia del poema, que recurre a lo fulminante (disparos de luz, deslumbramiento) y lo incendiario (cielos que arden), para sosegarse luego en la ancha luz cósmica (el semblante del río, como la faz del día; el blanco atardecer hilado). El imperio de la ciudad, que ciñe como cetro el globo terráqueo, es también de orden lumínico, y la final escalada hacia los espacios es signada por los ojos de astro de la urbe. Paralelamente a ello, la expresión del dinamismo urbano se universaliza desde el ajetreo trepidante de coches y trenes, elevándose a la majestad - con tono de epopeya - de las caudalosas corrientes y los giros astrales: el Spree que fluye ignoto, sin esperanza de ser salvado, hacia la inmensidad; la luz de la ciudad, planetaria, que alumbró mundos y lo calla. Doble sublimación, en luz y movimiento, del acontecer berlinés.

${ }^{8}$ Berlin: Die Stimmen der Autos wie Jägersignale / Die Täler der Straße bewaldend ziehn. / Schüsse von Licht. Mit einem Male / Brennen die Himmel auf Berlin. // Die Spree, ein Antlitz wie der Tag, / Das glänzend meerwärts späht nach Rettern, / Behält der wilden Stadt Geschmack, / Auf der die Züge krächzend klettern. // Die blaue Nacht fließt in der Forst. / Sie fühlt, geblendet, daß du lebst. / Schnellzüge steigen aus dem Horst! / Der weiße Abend, den du webst, // Fühlt, blüht, verblättert in das All. / Ein Menschenhände-Fangen treibst du / Um den verklungnen Erdenball / Wie hartes Licht; und also bleibst du. // Wer weiß, in welche Welten dein / Erstarktes Sternenauge schien, / Stahlmasterblühte Stadt aus Stein, / Der Erde weiße Blume, Berlin. 


\section{ATARDECER BERLINÉS 9}

¡Espectral deambular sin existencia!:

se ensombrece el asfalto y el gas le arroja

su luz; de la mezcla nace marfil.

Las calles, al acecho. Con olor a primavera.

Chillan —un rebaño de relámpagos — los coches

y se buscan unos a otros por las calles.

Luces como banderas, relumbrantes

muchedumbres: afluyen los tranvías.

Y hasta lo más lejos las luces de Berlín. Ya el Este,

el blanco viento, lleva en los dientes hielo,

y han rechinado sobre la ciudad sus lucientes fauces

que llevan el mudo pájaro de la noche encima. ${ }^{10}$

La celebrada proclama inicial, que consagra un indefinido pasear urbano sin sujeto ni presencia, ${ }^{11}$ contrasta con el inmediato registro de valores plásticos, exentos de asociación moral, pero ricos en placeres asociativos matéricos. Aquí levanta acta el habitante anónimo de la ciudad, en un primer verso sin rostro, que exige el infinitivo: un habitante sensible a la vez que entumecido, que presencia los prodigios a su alrededor pero es incapaz de ordenarlos en forma de emoción cívica. Toda la vitalidad es detentada por la ciudad, cuyos agentes inmateriales (asfalto, gas, calles, coches, luces) se entregan a un trajín alquímico y alucinado. Señala Krause (2015: 115) que los coches, al buscarse mutuamente por las calles, adquieren un protagonismo activo del que carecen las personas, desvaídas como muchedumbre o como espectrales paseantes «sin existencia»; la hermosa vitalidad de la ciudad, arrolladora y loca, es compatible con el aroma primaveral.

En la tercera estrofa, nombrado por vez primera, un Berlín desbordante, que dilata sus luces hasta la lejanía, es avasallado a su vez por fuerzas naturales demoniacas: el Este, el viento, el hielo, la noche. Es un juego telescópico de anulación sucesiva; el individuo, devorado por la ciudad; la ciudad, devorada por el cosmos.

\section{CORAZÓN DE FEBRERO ${ }^{12}$}

Como si las mujeres, en su tocado de plumas de avestruz, la joven luz llevaran cual un penacho blanco,

${ }^{9}$ En Die Aktion, 3 (número especial), 8-I-1913, p. 41, y en Jünge Pferde! (Boldt, 1914: 27).

10 Berliner Abend: Spukhaftes Wandeln ohne Existenz! / Der Asphalt dunkelt und das Gas schmeißt sein / Licht auf ihn. Aus Asphalt und Licht wird Elfenbein. / Die Straßen horchen so. Riechen nach Lenz. // Autos, eine Herde von Blitzen, schrein / Und suchen einander in den Straßen. / Lichter wie Fahnen, helle Menschenmassen: / Die Stadtbahnzüge ziehen ein. // Und sehr weit blitzt Berlin. Schon hat der Ost, / Der weiße Wind, in den Zähnen den Frost, / Sein funkelnd Maul über die Stadt gedreht, / Darauf die Nacht, ein stummer Vogel, steht.

${ }^{11}$ Invirtiendo de paso la figura del flâneur baudeleriano.

${ }^{12}$ Recogido en Jünge Pferde! (Boldt, 1914: 36). 
y todas las casas pertenecieran a ricos navieros

y se volvieran barcos, así, en torno a los balcones

está nadando el aire azul. ¡Oh, ir ahora en canoa

sobre las aguas, como el sigiloso cisne

poner rumbo a dulces nieblas mañaneras,

partir las olas con el negro timón!

¡Vete a la calle Leipzig! ¡Sal al aire!

¡Hermoso es el placer! Dios es un buen mozo.

¡Las putas se solean, más fogosas que tiburones!

¡Tengo dinero! Estoy tan bien de ritmo.

¡Sonetos de sol me cosquillean en la lengua!

¡En la garganta se me agolpan los gritos! ${ }^{13}$

Boldt ofrece aquí un ramillete primaveral, perfumado de sensualidad y alegría de vivir. La gran ciudad es celebrada como pura invitación a salir y gozar. Las imágenes generales, aéreas, placenteras y saturadas de atmósfera, rehúyen el repertorio frecuentemente nocturno y opresivo de los expresionistas. El soneto es una ilustración literaria de la pintura au plein air y del impresionismo. En la brillante fórmula «sonetos de oro me cosquillean en la lengua» se materializa la inspiración poética, que el poema consagra, mercenariamente, al servicio de devaneos y lances de los que exigen su dosis de dinero y facundia.

El poema aprovecha la estructura estrófica para sugerir la transición desde un impreciso bienestar atmosférico y anhelo de expansión (cuartetos), hasta la concreción predatoria y háptica del deseo (tercetos). Lo aéreo se condensa. Como el soneto de oro corporeiza la inspiración poética, también la marchosería y el dinero activan otros engranajes de la máquina berlinesa. Estos tres dones, como en un cuento, franquean el acceso a tres estampas sacras de la vida urbana: tertulias de café, paseos de bulevar, abrazos de prostituta. El verso final se ha traducido con asumida renuncia interpretativa, aceptando la polisemia de «Schreie», gritos, aunque todo el contexto parece remitir al relincho juvenil, el jijeo.

Como en otros sonetos aquí incluidos, Boldt hace uso de una métrica libremente inspirada en los modelos canónicos — parece evocarse la estructura del soneto inglés, $\mathrm{ABAB}$ CDCD EFEF GG-, si bien las desviaciones con respecto al modelo son grandes: aquí es $A B A B$ BCBC DED EED, con tres serventesios y dos versos sueltos, que recapitulan las rimas del último serventesio sin formar pareado; la repetición de rimas alienta una sensación de ligera euforia maníaca. La disposición gráfica en el original, discrepante

${ }^{13}$ Mein Februarherz: Als trügen Frauen in den Straußenfedern / Das junge Licht wie eine weiße Fahne, / Gehörten alle Häuser reichen Rhedern / Und wären Schiffe, schwimmt um die Altane // Die blaue Luft! Oh, jetzt in einem Kahne / Auf Wassern fahren, süßen Morgennebeln / Entgegensteuern, gleich dem leisen Schwane / Die Wellen teilend mit den schwarzen Hebeln! // Geh in die Leipzigerstraße! Geh ins Freie! / Schön ist die Wollust! Gott ein guter Junge. / Die Dirnen sommern brünstiger als Haie! // Ich habe Geld! Ich bin so schön im Schwunge. / Sonette aus Sonne kitzeln mir die Zunge! / In meiner Kehle sammeln sich die Schreie! 
con la estructura rímica, se organiza con dos cuartetos y dos tercetos. ${ }^{14}$ Los dos versos finales rematan el texto con una síntesis aforística, que muestran dos caras del habla: la elaboración cultural (sonetos) y el grito primordial (jijeos).

EN LA TERRAZA DEL CAFÉ JOSTY ${ }^{15}$

Con eterno mugido, la Plaza de Posdan

trueca en glaciares los retumbantes aludes

del callejero: tranvías sobre rieles,

automóviles y la basura humana.

Las gentes chorrean sobre el asfalto,

diligentes como hormigas, ágiles como lagartos.

Las frentes y las manos van con cegador pensar

flotando, como jirones de luz en bosque umbrío.

La lluvia de la noche envuelve la plaza en su cueva,

con blancos murciélagos de batientes alas,

y por el suelo, de irisado aceite, medusas lilas:

los coches, rebanándolas, las multiplican.

Y Berlín, redoma de luces de día, va brotando

del humo de la noche como pus de una herida. ${ }^{16}$

Flora y fauna tapizan, como en cuadro de los antiguos maestros, esta celebrada estampa. ${ }^{17}$ Lo inanimado y material es dotado de vida orgánica o elevado a la dignidad de lo telúrico. El Café Josty, refugio de las artes, el ocio y el negocio, era el epítome de la nerviosa vida berlinesa, con el ya entonces desbordante tráfico, la caudalosa y multiforme vida de las aceras, las trampas y peligros de la gran ciudad. En la fanfarronada del urbanita, todo sirve a la vanidad etnocéntrica, tanto si rebaja hasta lo degradante, como si ensalza hasta lo imposible. Por ello lo elevado y lo ínfimo coexisten en apretada sucesión dentro del poema, mediante inestables equilibrios, que impiden el cierre semántico.

\footnotetext{
${ }^{14}$ Igual disposición, con dos tercetos, encontramos en el soneto siguiente («En la terraza del Café Josty»), más cercano al modelo isabelino. Sobre la apropiación heterodoxa del soneto por los expresionistas, como paradójico molde transgresor, véase Grätz (2019: 238).

${ }^{15}$ Publicado en Die Aktion, 2 (46), 13-XI-1912, p. 1456. Traducido al español: Armas (2016); al portugués: Barrento (2001: 55); al francés: Scheiffele (2005); al inglés: Pettit (GHDI).

${ }^{16}$ Auf der Terrasse des Café Josty: Der Potsdamer Platz in ewigem Gebrüll / Vergletschert alle hallenden Lawinen / Der Straßentrakte: Trams auf Eisenschienen, / Automobile und den Menschenmüll. // Die Menschen rinnen über den Asphalt, / Ameisenemsig, wie Eidechsen flink. / Stirne und Hände, von Gedanken blink, / Schwimmen wie Sonnenlicht durch dunklen Wald. // Nachtregen hüllt den Platz in eine Höhle, / Wo Fledermäuse, weiß, mit Flügeln schlagen / Und lila Quallen liegen -bunte Öle; // Die mehren sich, zerschnitten von den Wagen. - / Aufspritzt Berlin, des Tages glitzernd Nest, / Vom Rauch der Nacht wie Eiter einer Pest.

17 A diferencia de los otros poemas recogidos en esta selección, cuenta con una acertada traducción al español, de Montserrat Armas (2016). No obstante, he considerado oportuno proponer esta variante, que enfatiza algunos aspectos de mi interés.
} 
El primer cuarteto convierte el tráfico en alud, enfriado luego por el alienante mugido hasta volverse poderoso e irrevocable como un glaciar. Paradójicamente, el tiempo rápido del tráfico y el bullicio se expresa con metáforas de la extrema lentitud, de orden geológico: el mugido eterno, los glaciares. Hay en ello una operación de radical distanciamiento, como en la mirada displicente de una deidad cansada; la anécdota es devorada por el proceso, y el detalle de las biografías se vuelve irrelevante. El glaciar arrastra, con enumeración degradante, tranvías, coches y «la basura humana». Progresión desvalorizante que se invierte, sin embargo, en el segundo cuarteto; la muchedumbre está compuesta por hormigas, ciertamente, pero —en referencia al avispado berlinés, al que no se le escapa una-, no dejan de ser lagartos. Y por encima flota luminoso el pensamiento. Una oposición análoga se plantea en el pareado final. ${ }^{18}$ Berlín es nido o cuenco de las luces de día, pero de noche brota como pus de una herida. La primera caracterización es compatible con el ditirambo, apuntando al elogio convencional como ciudad de luces; la segunda precipita el teatro nocturno en la más hirviente putrefacción. Y sobre todo ello, espesas notas cromáticas, como pintura en vivo, sobrepuestas pinceladas que se tachan y diluyen, impidiendo el veredicto moral en virtud de su propia exuberancia.

\section{BULEVAR VESPERTINO ${ }^{19}$}

La calle está irradiada de sonido, poblada de fantasmas de perfume, y caderas en estuche de paño azul, que a cada paso muelen fino encanto.

Las fulanas vienen, restallantes, forraje de placeres, y damiselas burguesas, que racanean sus bellezas; unas doncellas, y otras que ya mudan la pluma, y cuelan entre el maquillaje una sonrisa escarlata.

Diablos, nos vamos a poner como pelícanos si estas muchachas nos siguen cebando con miradas. Codiciosos de contornos y trazados,

que vienen uno tras otro, sueltos, instantáneos; $\mathrm{y}$, girando los hombros regordetes, hasta las madres nos echan a los mozos, de tapadillo, una ojeada. ${ }^{20}$

\footnotetext{
${ }^{18}$ Nuevamente se acude a una variante del soneto inglés. El poema incluye dos cuartetos [ABBA CDDC EFE FGG] y transgrede la compartimentación en tercetos mediante una especie de encabalgamiento estrófico. El pareado final queda encubierto por su inclusión en un terceto gráfico.

19 Publicado en Die Aktion, 3 (17), 23-IV-1913, p. 452. Se incluye en Jünge Pferde! (Boldt, 1914: 37).

20 Abendavenue: Die Straße ist von Klängen überstrahlt, / Bewachsen von Phantasmen des Geruches, / Und Hüften in den Hülsen blauen Tuches, / Das aller Schritt zu Reiz zermalmt und mahlt. // Die Dirnen kommen, knarrend, Wollustfuder, / Und Bürgermädchen, die mit Reizen knausern; / Jungfräulein die, und andern, die schon mausern, / Gleitet ein Scharlachlächeln in den Puder. // Teufel! Wir werden wie die Pelikane / - Wenn diese Mädchen uns mit Blicken füttern, / Gierig nach den
} 
El paseo al atardecer por avenidas y bulevares es un molde central de la convivencia urbana a comienzos del siglo XX. Boldt despliega en este soneto un muestrario de erótica callejera, que recuerda los acentos golfos y vitalistas de Maupassant. Ya la primera estrofa sumerge al lector en una atmósfera de delicuescencia sensorial, donde se confunden los estímulos y lo evanescente toma el mando. Perfumes fantasmales que pueblan, sonidos que irradian; la anatomía femenina es un apretado molino que - usando la maquinaria de sus andares - espolvorea la tarde con harina de encanto. Una cascada de provocaciones se vierte sobre el paseante, y lo aturden con su variopinta seducción desde la fulana a la comedida burguesa, y la damita en ciernes que ya pasa contrabando de cruda sonrisa de carmín.

Con admirable aprovechamiento de las posibilidades del soneto, se produce una sabrosa transición al pasar a los tercetos: ${ }^{21}$ el tono es ahora de guiño y codazo, de cómplice camaradería viril. La inesperada imagen - tanta mirada pícara nos va a engordar como pelícanos - describe los efectos de una acción en viñetas, que alcanza en su sucesión de instantáneas una fusión cinematográfica. Y los dos versos finales ponen el broche lascivo: hasta las madres, guardianas de la moral, se vuelven para echar furtivas miradas deseantes.

\section{PASADA LA NOCHE ${ }^{22}$}

Las farolas, presagiando la tarde lluviosa, han vendido a la ciudad, la ciudad luciente. Como clara de huevo, gotea pus el aliento de luz de la calle Friedrich, donde las furcias rebullen.

Deshaciendo pliegues de párpados, los ojos reptan y te escupen con miradas que empapan.

De risas se les hincha la blusa; les ves los pechos, barrigas de sapo bajo el corsé.

Salías huyendo y los pájaros cantaban alboradas de junio.

La mañana se te clavaba en el rostro.

Campaneaban los relojes, despertaban el día.

Ladridos de dogo del toque de horas en la torre.

Abres la boca, y destellan los dientes. ¡Vagabundeos por el roquedal urbano! ¡Jadeos, clamores, rueda que triza almas!

Borbotea cremoso el arrebol mañanero.

Konturen und Profilen, // Die alle kommen, einzeln, momentane, / Und aus den fetten Rücken, aus den Müttern, / Bisweilen leise nach uns Jungen schielen.

${ }^{21}$ Los tercetos se ajustan a un peculiar esquema, [EFG EFG], que evoca las repeticiones del paseo burgués, donde se daban vueltas como en un carrusel.

${ }^{22}$ Incluido en Jünge Pferde! (Boldt, 1914: 45). 
Y callas. Tras los ojos sombríos descansa

el cerebro sus calambres de mortífero arsénico.

Sonríes, echas una mirada: y ahora entra en escena

el sol, juvenil, con tocado de nubes. ${ }^{23}$

Inquietante poema canalla, donde hacen acto de presencia dos protagonistas de la vida nocturna, habituales de la poesía expresionista: la prostituta callejera y la farola. En ambos habitantes de las sombras reside una conciencia luciferina; son agentes que iluminan y levantan acta de la noche, con luces y miradas; en los dos se expresa un paralelo desquiciamiento de los principios vitales. La luz enferma, la seducción venenosa.

Tal vez deriva Boldt de su infancia rural la noción supersticiosa del sapo que escupe, el bicho que envenena fuentes. Conseja que aquí traspasa a la prostituta. Potentes imágenes, de galantería a la inversa: los ojos reptan, saliendo del envoltijo de los párpados hinchados de trasnocheo; los senos son blancos y con tacto de barriga de sapo. $^{24}$

El cuarteto central introduce un compás cursivo, de fugaz relato: una narración en pasado, que mitifica la fuga por los laberintos de la noche. El poeta yerra por la ciudad rocosa de piedra, una ciudad que es rueda de tortura a la que están atadas las almas. Señala Krause (2006: 111) que esta rueda de tortura es la compulsión de placer y saciedad a la que voluntariamente se encadenan los urbanitas: el precio que pagar por su amor fati, su aceptación de un destino marcado. ${ }^{25}$ El poeta mismo es amenaza, y estos dientes que brillan incongruentemente son un contra-sol y aviso: el habitante de la ciudad es una fiera acosada. También la resaca, con calambres, y el lento veneno de los excesos se retratan en un cerebro que como pantera oscura descansa escondido.

Es sorprendente el cuarteto final, que teatraliza la ciudad con un golpe de efecto, destinado a contrapesar los diagnósticos sombríos de los versos anteriores. El poeta, incorregible actor, se recompone y sonríe para el público; el sol hace entrada, como un petimetre frívolo, y las nubes anunciadas en la estrofa primera le sirven de sombrero.

${ }^{23}$ Nach der Nacht: Laternen, die den Regenabend führen, / Haben die Stadt, die glänzende, verraten. / Eiweißer Eiter tropft im Lichteratem / Der Friedrichstraße, wo sich Dirnen rühren. // Die Augen kriechen aus den Faltenlidern / Und spritzen einen Blick, der dich begießt. / Sie lachen sich das Kleid vom Bauch; du siehst / Die Brüste - Krötenbäuche in den Miedern. // Du flohst, und Vögel sangen für dich junitags. / Der Morgen senkte sich in dein Gesicht. / Es schlugen die Uhren an, weckten das Licht. / Doggengebell des Turmuhrstundenschlags. // Du öffnest deinen Mund, der ist lichtzahnig. / O Wanderungen im Gestein der Stadt! / O Röcheln, Schreie, seelenquälend Rad! - / Es sprudelt aus der Morgenröte sahnig. // Du schweigst. Hinter den dunklen Augen ruht / Das Hirn vom Krampf der tötenden Arsene. / Du lächelst, blickst - und da betritt die Szene / Die Sonne, jugendlich, im Wolkenhut.

${ }^{24}$ El sapo, como alma gemela del poeta en su degradación, ya aparecía en un importante poema de Corbière (1873: 71), «Le crapaud»: «poète tondu, sans aile, / Rossignol de la boue...» («poeta trasquilado, sin alas, / ruiseñor del lodo...»). Boldt desplaza esta identificación hacia una figura obsesivamente presente en los paisajes urbanos expresionistas, la prostituta.

${ }^{25}$ Es tentador aludir, por razones etimológicas, al fado lisboeta — fado < FATUM—, presidido por la voluntaria inmolación en brazos de una vida de perdición: «Tenho o destino marcado / Desde a hora em que te vi // Ó meu cigano adorado / Viver abraçada ao fado / Morrer abraçada a ti» («Ó rua do Capelão», letra de Júlio Dantas); «se é pois um pecado / ter amor ao fado, / que Deus me perdõe» («Que Deus me perdõe», letra de João Silva Tavares). Pero sería ilusorio ver en esta temática un rasgo singular del fado, pues la canción popular europea y americana reincide sin cesar en la misma noción. 
$\operatorname{TILOS}^{26}$

Maquilladas de bosque y carmín de farolas

se adentran filas de tilos y alguna platanera ${ }^{27}$

- de la arboleda son las cortesanas-

entre fluyentes damiselas del Kurfürstendamm.

Doncellas boscosas con bucles de frondas:

habrá que ser viento para abrazaros.

Hermosas dríades, ¿soñáis con caseríos

ceñidos a arroyos y prados entre trigales?

Con dardo de luz en el verde cabello

ah, qué elegantes os habéis puesto,

señoritas judías —que yo, un bárbaro, amé,

con sangre de vendaval y norte bravío-.

Brilló la luna, se esfumó sin dejar traza

y ahora yace ahí, un huevo en nido de nubes. ${ }^{28}$

Poema galante, dirige cumplidos a la gentil arboleda urbana. La ciudad no es el opresivo espacio demoniaco del expresionismo sino una pasarela de beldades, mujeres o árboles, paseantes por una edad dorada ajena a la culpa, que invita a destilar nueva mitología (Mattenklott, 1987: 111). En la imposibilidad de poseer estas beldades arbóreas, que solo se dejan abrazar por el viento, resuenan elementos del mito de Dafne y Apolo.

Se estructura el soneto sobre el destino de los tilos de bulevar, exilados de la selva germánica, que tal vez añoran - como el poeta, nacido en la remota Prusia - los oriundos paisajes, de honda rusticidad. Pero los árboles, tilos y plátanos, han completado su ciclo de refinamiento, a diferencia del poeta, que aún es bárbaro, poblado de tempestades y septentriones. El epíteto que les dirige — judías_-, ha de entenderse como referencia a su sofisticación capitalina, siendo como son señoritas de gran clase elevadas sobre el común. En la obra de Boldt aparecen, como ecos de Baudelaire, otras evasivas y seductoras judías («Meine Jüdin», «Andere Jüdin»).

El pareado final [ABBA CDDC EFEF GG] no desempeña funciones de síntesis, sino que provoca un radical distanciamiento: la acción humana en el bulevar es reducida a miniatura, un pie de página bajo los aconteceres de una luna que, a su vez, es degradada

${ }^{26}$ Incluido en Jünge Pferde! (Boldt, 1914: 29). Traducción al francés: Scheiffele (2005).

27 Ambos árboles, tilo y plátano, son femeninos en alemán. Se acrecientan las dificultades de traducción por ser el nombre del árbol, plátano, polisémico y escasamente poético en español.

${ }^{28}$ Linden: Mit Wald gepudert und Laternenschein, / Schreiten die Linden und ein paar Platanen / - Unter den Bäumen sind sie Kurtisanen - / Den Mädchenstrom Kurfürstendamm hinein. // Ihr Wäldermädchen mit den Laubfrisuren - / Man muß wohl Wind sein, um euch zu umarmen. / Hübsche Dryaden, träumt ihr von den Farmen / Am Strom und Wiesen zwischen Weizenfluren? // Den Pfeil von Glühlicht in dem grünen Haar, / Aha! Ihr seid schon elegant geworden, / Jüdinnen, - die ich liebte, ein Barbar, // Im Blut Unwetter und den wilden Norden. / Es schien der Mond, verlor sich ohne Rest, / Jetzt liegt er da, ein Ei, im Wolkennest. 
a la condición de un huevo en su nido. Rápidos movimientos de zoom: de la escena urbana a la cósmica, de los astros al gallinero.

\section{ATARDECER DE NOVIEMBRE ${ }^{29}$}

Hace aire. El oro del poniente, una bandera que pronto ha de ser arrebatada por el viento. Un poco de otoño hay en los plátanos, un cromo chillón que se destiñe, se deshace.

En nubes como tizones aún se husmea el difunto sol; luego inhalar, acuciar, refrenar: las soledades afloran. ${ }^{30}$

Tonos contemplativos presiden este esbozo que convierte el paisaje urbano en naturaleza muerta. Las notas cromáticas se funden con las olfativas: los arreboles del poniente son rescoldos de una pira funeraria, y sensorialmente se acercan a la esfera del hogar, el tizón mal apagado de un cuarto estudiantil. Un paisaje que era oro y bandera va a ser desguazado como un escenario teatral al acabar la temporada. La soledad que viene suspenderá la pública representación en el bulevar, para devolver la acción al silencioso vivir del ser, que inhala, acucia, refrena: en un mero estar vivo, latiente pero despojado hasta lo doloroso.

\section{JAKOB VAN HODDIS (1887-1942)}

El seudónimo es un exacto anagrama de su apellido Davidsohn. Nacido en una familia judía de la burguesía berlinesa, brilla precozmente por su potente libertad creativa. Lucha con la locura, sufriendo varios internamientos que impiden, ante el espantoso sellado de la mazmorra nazi, su fuga a tiempo. Deportado en 1942 a Polonia, muere en un campo de concentración, Sobibor.

\section{CIUDAD $^{31}$}

¡Qué bella es esta altiva urbe de codicia!

Su miseria, su afrentoso despilfarro,

el intrincado ornamento de sus pesadas calles.

Desvergonzado, el día te marca los relieves.

Las casas se alzan mugrientas de polvo y hollín,

${ }^{29}$ Recogido en Die Aktion, 2 (47), 20-XI-1912, p. 1482, y en Jünge Pferde! (Boldt, 1914: 22).

30 Novemberabend: Es weht. Das Abendgold ist eine Fahne, / Die von den Winden schon erbeutet wird. / Ein etwas Herbst in der Platane, / Ein gelles Chrom verweht, verwird. // In Wolken gleich verkohlten Stämmen / Riecht man die tote Sonne noch; / Dann das Einatmen, Drängen, Dämmen - / Einsamkeiten kommen hoch.

${ }^{31}$ Compuesto hacia 1907-1909. Recogido en Van Hoddis (1958: 19). 
y entre el presuroso tráfico hormiguean

miedosas mujeres, hombres, pálidas prostitutas.

Largo tiempo escruto la presurosa pompa,

y trae regusto a sofoco el sabor del gentío:

sé con qué tesón secundan el mandato

del obtuso día, que sirve y reparte poderes.

[Y que los azuza al bien cercado redil].

Vamos: a esperar la llegada de la enfermiza noche

y la pesada carga, el zumbido, del pensamiento. ${ }^{32}$

El poema tiene hechuras de soneto reconstruido, con secciones iniciales que se cierran mediante rima abrazada (ligando el primero y último verso de cada una), un recurso que acentúa la autonomía de las estrofas. Entre la pompa de la ciudad representativa y bajo su altiva opulencia, el poema hace arqueología de miserias. El sol saca las vergüenzas, como el viento marca en un vestido una anatomía poco agraciada. La muchedumbre afanosa de la ciudad, que secunda sin titubeos las consignas de la vida laboral y los señuelos de la ambición, es reprobada por el poeta en un verso aislado, puesto entre corchetes, que parece un aparte teatral. Del otro lado de esta ciudad burguesa, diurna y precipitada, está el mundo nocturno, atormentado, enfermizo del artista.

\section{MEDIODÍA ${ }^{33}$}

Una risa diabólica rechina en el cielo azul y el seco polvo atormenta por las calles al bullicio de la extensa y revuelta ciudad. Tiesa hojarasca apostada sobre los árboles.

Como si el sol, yacente sobre un carromato, pasara lentamente, con resonante tintineo, la ciudad retumba, ebria, y entre lamentos marchas derrumbándote, tan solo como en el desierto, fiero y soberbio de más para buscar compañía o placer. Y ni siquiera te atreves a pedir de estas casas los sueños que de niño te sonreían.

${ }^{32}$ Stadt: Wie schön ist diese stolze Stadt der Gierde! / Ihr Elend und geschmähter Überfluß / Und schwerer Straßen sehr verzerrte Zierde. // Schamloser Tag entdeckt dir die Konturen. / Die Häuser stehn befleckt mit Staub und Ruß, / Es flirrt um Eilende und Wagenhaufen / Furchtsame Weiber, Männer, blasse Huren... // Ich starre lange in die schnelle Pracht / Ein Dumpfes ahnend drunten im Gedränge - / Ich weiß wie sie des blöden Tages Strenge / Gewaltig preisen: daß er herrschen macht. // [Es zieht sie nur zur wohlumbauten Enge.] // Komm! laß uns warten auf die kranke Nacht / Der schweren dröhnenden Gedankenpränge.

${ }^{33}$ Compuesto hacia 1912-1914. Recogido en Van Hoddis (1958: 56). 
De venenosa fruta está cargado el árbol de esta luna.

Solo la angustia se levanta. Aún en el más hondo sueño te asedian los vientos con negras muecas.

Así de día y de noche y sin nadie que los ahuyente. ${ }^{34}$

De nuevo truca Van Hoddis la forma del soneto, ampliado con un verso más y reestructurado como sucesión alternada de serventesios y tercetos [ABAB CAC DCDC ECE C]. La disposición gráfica rompe la estrofa final, desprendiendo un verso suelto, que adquiere el eco fatal de una sentencia. En las estrofas largas domina un tono descriptivo-acumulativo, mientras que la concisión de los tercetos gráficos es aprovechada para instalar ominosas asociaciones, de trazo vigorosamente libre. Las alternancias son bruscas, casi con quiebro de voz, entre trechos de sencilla exposición dolorida y arriesgados saltos a cadenas metafóricas. El primer verso abre con una potente sinestesia - literalmente, «una risa de diablo enseña los dientes en el cielo azul»— para descender seguidamente a una muy comedida descripción del paisaje urbano agostado. La misma caída desde una fogosa metaforización inicial, también sinestésica, se produce entre la segunda y tercera estrofas; tras un sol yacente, sobre carromato, que pasa atronando la ciudad, el yo poético se describe con sencillas palabras desoladas.

En el segundo terceto emerge un encuadre nocturno, con luna y pesadilla: de nuevo, la potente realidad paralela de la vida nocturna, el sueño y el desvarío, al margen del sol demoniaco que abre el poema. Hemos optado por la imprecisión botánica — «venenosa fruta»— para reproducir la referencia a la belladona, planta alucinógena bien conocida en el mundo germánico.

Detecta Vietta (1992: 300) en este y en otros poemas de Van Hoddis una nota dominante, el lamento, de proporciones casi bíblicas. Es un mundo asolado, donde las fuerzas ciegas de la naturaleza (sol, viento, luna) son hostiles, y la ciudad es árida como un desierto del que es imposible escapar.

\section{PAUL ZeCH (1881-1946)}

De familia rural, nacido en Briesen o Wąbrzeźno en Polonia, emigró adolescente a Wuppertal, en busca de trabajo, y conoció el paisaje negro de las minas de carbón del Ruhr y las acerías de Bélgica. En 1912 se asienta en Berlín y frecuenta el círculo de Sturm. Funda, con otros, la revista expresionista Das neue Pathos. Mitómano pertinaz, sus datos autobiográficos suelen ser ilusorios. Su exilio desde 1933 en Argentina lo dio

${ }^{34}$ Mittag: Ein Teufelslachen bleckt am blauen Himmel / Und in den Straßen quält der trockene Staub / Der breiten und verworrnen Stadt Gewimmel. / An allen Bäumen sitzt erstarrtes Laub. // Als hing die Sonne jetzt am Leiterwagen, / Der langsam fährt mit schallendem Gebimmel / Es dröhnt die Stadt wie trunken und in Klagen // Du gehst bestürzt, so einsam wie in Wüsten, / Zu wild und stolz nach Mensch und Lust zu jagen. / Und selbst nach Träumen, die als Kind dich grüßten, / Wagst du jetzt diese Häuser nicht zu fragen. // Tollkirschen trägt dir dieser Monde Baum. / Nur Ängste steigen auf. Die Winde schlagen / Dir schwarze Fratzen in den tiefsten Traum. // So Tag und Nach und niemals zu verjagen. 
a conocer en este país, donde algunos de sus poemas se han traducido (Rohland de Langbehn, Langbehn y Gianera, 1997; Piccoli, 2006).

\title{
CIUDAD FABRIL JUNTO AL WUPPER. LA OTRA CIUDAD ${ }^{35}$
}

\author{
Negra ciudad puesta en pie sobre las negras aguas: \\ refulgen ventanas de párpados en verde; \\ en fantasmales penumbras sobre tejados de pizarra \\ se afanan chimeneas, ensombrecidas de vapor y humo. \\ Luciente y bravo traquetea el tren lanzadera \\ pasando puentes y escuálidas callejas. \\ La fábrica, allá abajo, donde giran chirriantes los husos, \\ es gris como una barcaza cansada y podre. \\ El sudor pega con cola las desmigajadas grietas, \\ un sudor vinagre de tanto zumo de sangre, \\ y santurrona pus supura de achacosas vejeces. \\ Muchos enfangaron y perdieron aquí el corazón; \\ muchos engendraron niños con mujeres famélicas. \\ Iglesias y comercios siguen duros, como forjados en hierro. ${ }^{36}$
}

Ambientado en pleno corazón del Ruhr, este soneto muestra vislumbres de la intensa industrialización. Con tono enfático, se salmodian versos sobre el barrio minero, privilegiando las notas negras y pútridas, con intensificaciones expresivas en la tradición apocalíptica-industrial que ensayaron Hugo y Zola. Un antecesor más próximo de esta dicción poética está en los broncos versos de Verhaeren, cuya obra Les Blés Mouvants fue traducida al alemán por Zech. Ocupa una posición central en el poema la dualidad entre lo mineral - a través de acentos de sombra y negro, referencias a vapor y humo, la dura pizarra de las fábricas, el hierro forjado que simboliza a la iglesia o el comercio-, y lo orgánico - la vida humana de fango y perdición, el colectivo sudor, aglutinante que repara grietas, la pus que se vuelve piedad- Los dos versos finales, soldados por la rima [ABBA CDDC EFE FGG], remachan esta oposición, «schwachen Fraun» / «aus Erz gehauen» («débiles mujeres» / «[iglesias y comerciantes] hechos de hierro»).

35 Compuesto hacia 1911-1912, aparece por vez primera en Der Sturm (Zech, 1913: 127), dedicado a Else Lasker-Schüler que, nacida en Wuppertal, vivía en Berlín. Hace conjunto con otro soneto, que describe la ciudad palaciega, de los propietarios. Poco después se incluye en el libro de poemas Die eiserne Brücke (Zech, 1914: 70).

${ }^{36}$ Fabrikstadt an der Wupper. Die andere Stadt: Schwarze Stadt an schwarzem Gewässer steilaufgebaut - / Grünbeliderte Fenster funkeln, / aus dem gespenstischen Schieferdachdunkeln / schnelln Schornsteine von Dampf und Dunst umbraut. // Hellwild rattert und knattert die Pendelbahn / über Brücken und hagre Alleen. / Fabrik dort unten, wo Spindeln sich kreischend drehen, / ist grau wie ein müder vermorschter Kahn. // Schweiß kittet die bröckelnden Fugen fest, / Schweiß aus vielerlei Blutsaft gegoren / und ein Frommsein enteitert dem greisen Gebrest. // Mancher hat hier sein Herz verludert, verloren; / Kinder gezeugt mit schwachen Fraun... / Doch die Kirchen und Krämer stehn hart wie aus Erz gehaun. 


\section{LA CIUDAD PROSAICA ${ }^{37}$}

Calle arriba, calle abajo recorremos la ciudad, la gris ciudad, la ciudad de puentes fatigados.

Mendigos andrajosos esgrimen malignos las muletas y los buhoneros nos aplastan contra las casas.

De la ventana de los figones revolotea olor pringoso de asado y vocea el alborozo de un sinfín de salas de música.

Forasteros, hemos de apretarnos bien los cintos y pasar encorvados bajo baldones y blasfemias.

Planea sobre el paseo el llanto de las sirenas de barco y desconsiderado estruendo de trenes nos echa plomo en los nervios. Por las grietas del adoquinado crecen enormes los hierbajos.

Algunos tilos tullidos se alzan junto al canal.

Campanas desafinadas gimotean tapando gozos y duelos

y por ningún lado se ven niños arremolinados para el juego. ${ }^{38}$

En esta otra pieza se describe una ciudad cejuda e industriosa, sumida en un ciego trajín que prohíbe el juego infantil y arroja de su seno al ocioso visitante. Es un mundo tóxico, donde la vida vegetal está desquiciada: los árboles crecen tullidos, pero las malas hierbas prosperan gigantescas.

\section{ERNST WILHELM LOTZ (1890-1914)}

Nace a orillas del Vístula, en el corazón de la actual Polonia, hijo de un preparador a domicilio para academias militares. Vivió en distintas ciudades alemanas y emprendió carrera militar, llegando pronto a oficial. En 1911 abandona el ejército y se dedica al comercio, cultivando la poesía y la traducción (Rimbaud, Verlaine). Voluntario en la guerra mundial, cabe llorar su muerte, con 24 años, en las trincheras del frente francés, en el mismo umbral de una lengua que había amado.

\footnotetext{
${ }^{37}$ Recogido en el libro Die eiserne Brücke (Zech, 1914: 67), el poema es de 1911-1912.
}

${ }^{38}$ Die nüchterne Stadt: Straßauf, straßab durchstreifen wir die Stadt, / die graue Stadt, die Stadt zermürbter Brücken. / Verlumpte Bettler drohen giftig mit den Krücken / und Händler drücken uns an Häusern platt. // Aus Wirtshausfenstern wirbelt fetter Bratgeruch / und Lustgebrüll aus hundert Singspielhallen. / Wir müssen schnell die Riemen fester schnallen / und ducken uns vor Fremdenhaß und Lästerfluch. // Den Korso überwölkt Geheul von Schiffsfanfaren / und Bahngeräusch bleit sich in unsre Nerven rücksichtslos. / Aus Pflasterritzen wuchert Unkraut riesengroß. // Verkrüppelt stehn paar Linden am Kanal. / Verstimmte Glocken überwimmern Lust und Qual / und nirgend sieht man Kinder, die sich um ein Spielwerk scharen. 


\section{LAS NOCHES ESTALLAN SOBRE LA CIUDAD ${ }^{39}$}

Las noches estallan sobre la ciudad, la salvaje, ardiente luz nos despedaza y como locos hilos flotan nuestros nervios en el viento sobre adoquines que levantan las ruedas.

En el café se nos encendieron abruptas voces sobre las frentes y se inflamó joven la sangre: ya saltaban las llamas: pero, temerosos aún del ardor propio, buscamos calma en la ceniza.

Ociosos deambulamos por las horas del día, en esquinas claras abordamos a muchachas. Demasiado apreciamos aún las decrépitas delicias del amor, que tan fácilmente pueden pagarse.

Nos hemos entregado al día

y sin recelo dejamos que nos lleve el viento, muy seguros de arribar al sitio preciso, cuando estemos hechos. ${ }^{40}$

Ejercicio de introspección generacional, el poema explora la instalación vital de su grupo de edad en un marco urbano frenético y provocador que alcanza su paroxismo en la vida nocturna. El tráfico rodado crea su propio microclima, un viento sobre adoquines; la iluminación artificial, como en otros textos de la época, es sentida como desquiciante. Frente a estos estímulos extremos, el sujeto plural del poema escoge cierta provisional reserva, fugándose a la amable ligereza del día: una belle époque cercada por monstruos. Las incendiarias discusiones en el café no llegan a mayores; los peligros de la pasión son conjurados eligiendo el fácil y rutinario amor venal; el ocio diurno y sus esquinas claras ponen contrapunto a la crispada noche.

En el cuarteto final parece contenerse una proclama profética: la generación se deja llevar confiada, adonde los vientos quieran; sus miembros no dudan de que su liviana maduración al sol los pondrá en situación de disponibles cuando estén fraguados. Sobre patines y esquíes, entre gratos flirteos y deportes al sol, una generación bogaba plácida hacia las prietas filas de la guerra.

${ }^{39}$ Pertenece a su colección Wolkenüberflaggt (Lotz, 1917: 55).

${ }^{40}$ Die Nächte explodieren ...: Die Nächte explodieren in den Städten, / Wir sind zerfetzt vom wilden, heißen Licht, / Und unsre Nerven flattern, irre Fäden, / In Pflasterwind, der aus den Rädern bricht. // In Kaffeehäusern brannten jähe Stimmen / Auf unsre Stirn und heizten jung das Blut, / Wir flammten schon. Und suchen leise zu verglimmen, / Weil wir noch furchtsam sind vor eigner Glut. // Wir schweben müßig durch die Tageszeiten, / An hellen Ecken sprechen wir die Mädchen an. / Wir fühlen noch zu viel die greisen Köstlichkeiten / Der Liebe, die man leicht bezahlen kann. // Wir haben uns dem Tage übergeben / Und treiben arglos spielend vor dem Wind, / Wir sind sehr sicher, dorthin zu entschweben, / Wo man uns braucht, wenn wir geworden sind. 


\section{AHÍ ESTÁN LAS CALLES ${ }^{41}$}

Ahí están las calles, anchas y vocíferas de luz, alto, en nubes, se alza el polvo y se enciende; por medio, asediadas columnas de coches se fugan hacia la penumbra violeta.

Y los hombres, en masa ennegrecida, asaltan las calles, corvos, al trabajo forzados. Y repica el fin de jornada desde las torres de la ciudad, extraviado, alto, desoído.

Ruido contra ruido. Dolorosos timbres tañen, aserrando el oído. Coches con acero tabletean. El tranvía, con estridentes chirridos al roce, toma la curva sobre rieles.

Y la malla de mis nervios, de tan sensible hilo, con perlas prendidas del mar perpetuo, es como tapiz extendido en el polvo, y cruel se repantinga el día en su seno. ${ }^{42}$

La estructura del poema convierte al ruido de la ciudad en actor, relegando al yo poético a la condición de simple víctima. Es una acústica plural y simultánea, a la que se suman sinestésicamente los efectos luminosos («Licht-durchschrieen» equivale a «atravesadas por gritos de luz»). La fina maquinaria sensible del poeta se vuelve irrelevante, la sirena que llama al descanso es desatendida, y de nada sirven los dones clásicos - con expresión tan remilgada que parece paródica: hilos donde se engastan perlas del mar eterno - ante la brutalidad del día y sus fenómenos. Sobre este delicado tapiz, la luz solar hoza, se revuelca o repantinga («sich wälzt»), expresión que consagra la violación de lo sensible por lo bruto. ${ }^{43}$

${ }^{41}$ Publicado, con otros poemas, en una hojilla volante, Und schöne Raubtierflecken... (Lotz, 1913).

${ }^{42} \mathrm{Da}$ sind die Straßen ...: Da sind die Straßen weit und Licht-durchschrieen, / Hoch wölkt der Staub und breitet aus den Schein, / Durch den gehetzt Kolonnen Wagen fliehen / In violette Dunkelheit hinein. // Und Menschen, massenhaft und schwarz, durchstürmen / Die Straßen, vorgebeugt und frongebannt. / Und Feierabend läutet von den Türmen / Der Stadt, verloren, hoch und unerkannt. // Lärm stößt an Lärm. Schmerzhelle Klingeln schellen, / Zersägend das Gehör. Wagen mit Eisen / Erschüttern. Die Elektrische mit grellen / Schleiftönen nimmt die Kurve in den Gleisen. // Und meiner Nerven Netz, so fein besaitet, / Drin Perlen hängen aus dem ewigen Meer: / Es ist als Teppich in den Staub gebreitet, / Und gräßlich wälzt der Tag sich drüberher.

${ }^{43}$ Como en otros poemas expresionistas, la luz del día y el firmamento son percibidos como potencias extrañas que avasallan sin piedad. Así en «Der Ausflug» de Lichtenstein (1962: 53): «el cielo, de descabellada grandeza, / mortalmente azul, / inmaculado» («den unsinnig großen, / Tödlich blauen, blanken Himmel»: hay traducción de Modern, 1958: 124). 
Nacido en Wuppertal, corazón industrial de Renania, recibió una cuidada educación. La Gran Guerra lo marcó indeleblemente; tras presenciar atrocidades sin cuento en Oriente Medio, su testimonio fue decisivo en la denuncia del genocidio armenio. Prisionero bajo el nazismo, se exilia en Italia. Su labor literaria confluye con otros intereses. Destaca por un libro de poemas de ciudad (Das Antlitz der Städte, 1917), donde se aleja de la línea central del expresionismo, al cubrir con intención exploratoria aspectos varios del paisaje urbano, componiendo un álbum de recuerdos y estampas viajeras.

\section{MONTMARTRE ${ }^{44}$}

La niebla llena, como una polvorienta nube, la plaza. Muerto de sueño pende el ramaje.

De los cafés sale a empellones el ruido y desollada resuena una risa.

Como sombras se deslizan las prostitutas

y por la penumbra se oyen susurros.

El cielo, con mano clara,

se desborda tras el alero.

En las pétreas ciudades, al alba, cuando, fatigados de noche, desvalidos y sin amarra, vuelven los hombres a ser niños, van con el brazo ciñendo el corsé de la prostituta y creen hallar un corazón de madre que con suave vigor los lleve a casa. Pero en su alma el dolor, antiquísimo, se despierta; y con labios henchidos de penas dejan borbotear palabras de amor, ridículas e innumerables, sobre los oídos cerrados de las mujeres. La noche, gris, va reculando por las callejas, pero la prostituta sigue en silencio.

Solo, en secreto, besan sus ojos el dinero que, como una flor dorada, guarda su mano marchita. ${ }^{45}$

${ }^{44} \mathrm{El}$ poema forma parte de una galería de apuntes parisinos («Pariser Silhouetten»). Compuesta entre 1909 y 1913 (Wegner, 1917: 60-61), se ajusta a su preferencia, desarrollada más tarde, por la evocación de viajes y ciudades.

${ }^{45}$ Montmartre: Nebel füllt, eine Wolke von Staub, / Den Platz. Schlaftrunken hängt das Laub. / Aus den Kaffeehäusern dringt Lärm herüber, / Und ein Lachen klingt roh. / Dirnen streifen wie Schatten vorüber, / Und im Dunkel flüstert es irgendwo. / Der Himmel, eine helle Hand, / Reckt weit sich über den 
«Montmartre» describe el final de la noche en la gran ciudad. El cansancio preside, con tonos grises, la hora lenta. El poema ordena dos estrofas de metro irregular. La primera esboza un paisaje impreciso con pinceladas amplias; la segunda marca una progresión temporal: el lento avance de la aurora, simultaneado con el reavivarse del viejo dolor del desamparo. Asonancias irregulares consolidan el avance de los versos, sugiriendo un andar titubeante, de ligera embriaguez o fatiga. Apretando este discurrir temporal, como un hipo que estrangula el tiempo, un verso de dos sílabas: «Uralt», esto es, antiquísimo tal la infancia descolocada de los hombres. El noctámbulo, desasido, es un barco sin amarra y su vida vacilante bate contra un paisaje hermético: las pétreas ciudades, el corsé que tapa cuerpos, los oídos sellados de las mujeres. El día que nace se acuña en la moneda de la prostitución; la mirada femenina no busca el sol naciente sino su correlato monetario, apresado en mano marchita. El pulso de la luz que crece está narrado en la sucesión desde el ramaje ceniciento y amodorrado de los primeros versos hasta el dorado florecer del dinero en la coda.

\title{
Alfons PETZOLD (1882-1923)
}

Podría encuadrarse a este vienés, de familia trabajadora y simpatías socialistas, como poeta obrero. Su obra, tanto en prosa como en verso, es parcialmente autobiográfica. Su visión de la ciudad, de acentos futuristas, es condenatoria y moralizante.

\author{
GRAN CIUDAD ${ }^{46}$ \\ Los carteles arrojan proclamas abigarradas \\ al torbellino de gentes y carruajes. \\ Mastodontes de acero, los coches corren. \\ Todo retumba: raíles, andamios, adoquines. \\ Los mazacotes de granito en calles y plazas \\ brillan plateados como ojos de insecto, \\ y en la altura la red de hilos de telégrafo \\ destella maligna y escupe su rencor al día.
}

Los escaparates lucen como cuevas de par en par, vuelcan el fasto de sus tesoros en mentes y corazones.

¡Adelante!, de traqueteos y berridos sube la voz.

¡Adelante!, gritan todos, ninguna mirada sube al cielo. ${ }^{47}$

Häuserrand. // In den steinernen Städten gegen Morgen, / Wenn die Menschen müde geworden / Von der Nacht, / Werden sie wie die Kinder wieder, / Hilflos und ohne Halt, / Legen den Arm um ein Dirnenmieder, / Glauben, es sei ein Mutterherz, / Das sie heimträgt mit sanfter Gewalt. / Aber in ihrer Seele der Schmerz, / Uralt, / Wacht auf; und mit Lippen voll Qual / In das verschlossene Frauenohr / Stammeln sie Liebesworte empor, / Sinnlos und ohne Zahl. / Grau die Nacht aus den Gassen steigt, / Aber die Dirne schweigt. / Ihr Auge nur küßt heimlich das Geld, / Das sie wie eine goldene Blume / In ihren welken Händen hält.

46 El poema forma parte de su libro de poesía social Der Dornbusch (Petzold 1919). Hay traducción al inglés, de William Ruleman (2017: 241). 
Como en un texto futurista, simultaneidad y dinamismo presiden esta descripción, donde las fuerzas brutas de la ciudad están personificadas y la figura humana se eclipsa. Solo la estrofa final contiene referencias a un público pasivo, nutrido por los escaparates. Aquí emerge un encuadre moralizador, inhabitual en la poesía urbana de la época: la mención aliterativa a «Hirn und Herz» — cerebro y corazón—, la censura a una sociedad que no mira al cielo.

\section{ALFRED LICHTENSTEIN (1889-1914)}

Hijo de un gran industrial textil, berlinés, estudia Derecho, iniciando carrera militar en 1913. Frecuenta cafés literarios y se impregna de las innovaciones del momento, especialmente del estilo grotesco y juguetón del también judío Van Hoddis. Adquiere inmediata resonancia y ejerce una influencia que se proyecta más allá de su deplorable muerte en el frente de guerra francés, en Picardía.

\section{LA NOCHE ${ }^{48}$}

Junto a las farolas se tambalean embobados los policías.

Descoyuntados mendigos lanzan al pie del transeúnte balidos.

Por las esquinas tartamudean vigorosos los tranvías

y plácidos taxis resbalan hacia las estrellas.

En torno a casas despiadadas van renqueando las putas, con el melancólico bamboleo de sus traseros maduros.

Mucho cielo yace hecho trizas sobre las amargas figuras...

Gatos apasionados andan gritando, dolidamente, agudas canciones. ${ }^{49}$

La experimentación con lo grotesco practicada por Van Hoddis y Lichtenstein tiene aquí un ejemplo característico, en dos apretados cuartetos. La primera estrofa traza, como los cuadros de Chagall, un paisaje presidido por la ingravidez. Asociaciones incongruentes, ligeramente levitantes y ebrias, proponen un mundo urbano invertido, donde los policías se abstraen y trastabillan, los tranvías tartamudean y los taxis se

${ }^{47}$ Großstadt: Plakate schmettern ihre buntfarbigen Phrasen / in das Gewühle der Menschen und Wagen hinein. / Die Stahlelephanten der Automobile rasen / alles tönt: Gerüste, Schienen, verblocktes Gestein. // Die granitenen Würfel der Gassen, Straßen und Plätze / silbrig, wie Augen eines Insektes glühn / indes in der Höhe die Telegraphendrahtnetze / bös funkeln und Trotz in die Sonne sprühn. // Schauläden prunken, gleich aufgerissenen Höhlen, / schütten den Glanz ihrer Schätze in Hirn und Herz. / Vorwärts! Dröhnt es aus dem Knattern und Gröhlen / Vorwärts! schreit alles, kein Auge blickt himmelwärts.

${ }^{48}$ Compuesto en abril o mayo de 1911, se publicó en Die Aktion, 2 (37), 11-IX-1912, p. 1165 (Lichtenstein, 1962: 44). Traducciones al inglés: Gilman, Levine y Radford (2000: 110), Lach-Newinsky (2010)

${ }^{49}$ Die Nacht: Verträumte Polizisten watscheln bei Laternen. / Zerbrochne Bettler meckern, wenn sie Leute ahnen. / An manchen Ecken stottern starke Straßenbahnen, / Und sanfte Autordrosschken fallen zu den Sternen. // Um harte Häuser humpeln Huren hin und wieder, / Die melancholisch ihren reifen Hintern schwingen. / Viel Himmel liegt zertrümmert auf den herben Dingen... / Wehleidige Kater schreien schmerzhaft helle Lieder. 
desploman hacia las estrellas. ${ }^{50}$ En contraste, la segunda estrofa plantea una lacerante caída: el idilio de la creación divina yace hecho añicos sobre la vida de las prostitutas; la ley de la gravedad - ahora sí plenamente activa - tiraniza sus cuerpos ya marchitos: del conjunto solo se eleva la voz amorosa de los gatos, destinada a perderse por los recovecos menos oficiales de la ciudad.

Hay diferencias también en el tono de las dos estrofas. El primer cuarteto es atrevido y paródico. La expresión del movimiento urbano recurre a verbos crudamente corporales y pecuarios: «watscheln», «meckern», «stottern» equivalen literalmente a andar como un pato, balar y tartamudear; el uso del epíteto es también inesperado y provocador. El segundo cuarteto, por contraste, es de tono más llanamente descriptivo: da comienzo con una larga cadencia aliterativa — «Um harte Häuser humpeln Huren hin und wieder»—, ${ }^{51}$ que ennoblece la expresión, aunque la síncope de planos en el segundo verso, «melancólico» frente a «traseros», implica un retorno parcial a la irreverencia. El verso final contiene un esquema aliterativo simétrico («Wehleidige» / «heller Lieder»; «schreien schmerzhaft») que lo dota de un equilibrio fonético desmentido por la banalidad del contenido.

Lichtenstein explora aquí una forma extrema de Reihungsstil (que podría traducirse como estilo-ristra, versificación en staccato) ${ }^{52}$ Este estilo, coherente con una visión descoyuntada de lo real, permite ensamblar collages mediante la sucesión de frases, a menudo ocupando cada una un verso, autónomas entre sí, sin obligación de congruencia con las próximas.

\section{NIEBLA $^{53}$}

Tan blandamente demolido el mundo por una niebla.

Exangües árboles se disuelven en humo.

$\mathrm{Y}$ oscilan las sombras cuando suenan gritos.

Bestias en llamas se esfuman como el aliento.

Las farolas de gas son moscas atrapadas.

$\mathrm{Y}$ aletean buscando escapatoria.

Pero de soslayo, con débil luz, en la alta lejanía,

la ponzoñosa luna acecha, gorda araña de la niebla.

Nosotros empero, que, desvariados, somos carne de muerte, con paso rechinante trizamos este esplendor desolado.

50 Dorit Müller (2004: 91) describe la técnica de Van Hoddis, que pone «en contacto los sustantivos con verbos y adjetivos incongruentes, con el resultado de que las cosas aparecen personificadas y las personas animalizadas o cosificadas».

51 Ya señalada por Giese (1992: 170).

52 No siempre coincide la unidad sintáctica y la métrica, aunque los poemas más característicos muestran esta segmentación en frases-verso (esticomitia; en alemán, Zeilenstil; en inglés, end-stopping). De Lichtenstein cabe citar «El crepúsculo», traducido por Modern (1958: 123) y Reina Palazón (2004: 270).

53 Se publicó en Die Aktion, 5 (39-40), 25-IX-1915, p. 496 (Lichtenstein, 1962: 59). Traducciones: al inglés, Gilman, Levine y Radford (2000: 131), Lach-Newinsky (2010); al italiano: Porena (1984). 
Y mudos hincamos los blancos ojos de miseria

como picas en el cuerpo hinchado de la noche. ${ }^{54}$

Lejos de ser un manto protector, velador de disonancias, la niebla es una tela de araña que viene a abolir el mundo y a consumar crímenes. Cómplices de la calma encubridora parecen las aliteraciones, susurrantes y reiteradas como pasos sigilosos: «die Welt so weich», «Blutlose Bäume», «Schatten schweben», «Brennende Biester», «Zerschreiten knirschend». El esquema metafórico es una continua inversión de los tropos románticos. La luna es una gorda araña, y el temblor de la luz en las farolas es un vano aleteo de mosca atrapada. El último cuarteto propone una danza macabra: un vago sujeto plural, desahuciado y perdido, alancea el cuerpo hinchado - como cadáver - de la noche. Pleonasmo del morir: agente y víctima son difuntos, la mirada es asesina, los pasos trituradores.

En su primera mitad, el poema, en el que predominan los pies yámbicos, sigue el ritmo en staccato del Reihungstil; a partir del verso séptimo se produce una transición hacia lo narrativo, expresada mediante tres frases encabalgadas.

\section{PAISAJE ${ }^{55}$}

Como huesos viejos yacen en la olla

del mediodía las calles malditas.

Tanto tiempo hace que no te veo.

Un chaval tira de la cola a una muchacha.

Y entre la basura unos perros se revuelcan.

Me encantaría ir del brazo contigo.

El cielo es un gris papel de estraza

y lleva el sol pegado, una mancha de manteca. ${ }^{56}$

Un idilio en clave menor se instala en la sordidez de la ciudad. ${ }^{57}$ Las banales frases de flirteo - tanto tiempo hace que no te veo [...] me encantaría ir del brazo contigo - van osadamente incrustadas entre escombro asociativo y descripción despojada, que retratan sin piedad el marco urbano. Escotillas hacia el deseo

${ }^{54}$ Nebel: Ein Nebel hat die Welt so weich zerstört. / Blutlose Bäume lösen sich in Rauch. / Und Schatten schweben, wo man Schreie hört. / Brennende Biester schwinden hin wie Hauch. // Gefangne Fliegen sind die Gaslaternen. / Und jede flackert, daß sie noch entrinne. / Doch seitlich lauert glimmend hoch in Fernen / Der giftge Mond, die fette Nebelspinne. // Wir aber, die, verrucht, zum Tode taugen, / Zerschreiten knirschend diese wüste Pracht. / Und stechen stumm die weißen Elendsaugen / Wie Spieße in die aufgeschwollne Nacht.

${ }^{55}$ Lichtenstein (1962: 48). Traducciones al inglés: Gilman, Levine y Radford (2000: 138), LachNewinsky (2010).

${ }^{56}$ Landschaft: Wie alte Knochen liegen in dem Topf / Des Mittags die verfluchten Straßen da. / Schon lange ist es her, daß ich dich sah. / Ein Junge zupft ein Mädchen an dem Zopf. // Und ein paar Hunde sielen sich im Dreck. / Ich ginge gerne Arm in Arm mit dir. / Der Himmel ist ein graues Packpapier, / Auf dem die Sonne klebt -ein Butterfleck.

${ }^{57}$ Las calles «malditas» del poema reproducen la percepción expresionista de la ciudad como espacio condenado, expulsado de toda armonía. Heym compone en 1911 su importante «Verfluchung der Städte» (maldición de las ciudades): véase en Rothe (1981: 16). 
abruptamente abiertas en medio de la sucia, opaca violencia de la ciudad. El poema comienza y termina con sendas parejas de metáforas coordinadas: el cielo es papel de estraza y el sol una mancha de mantequilla; el mediodía es una olla cociendo y las calles son huesos viejos. En contraste con esta batería de metáforas degradantes, el enlace entre los dos cuartetos recurre a la llaneza más rasa: «un chaval tira de la cola a una muchacha. / Y entre la basura unos perros se revuelcan». Anidando entre la obertura y el cierre, metafóricos, y el enlace, factual, progresa en sendas frases simples el negocio amoroso. Transiciones audaces, pero una clarísima conciencia de la arquitectura del poema. Y escenificación del amor urbano, que va a lo suyo abriéndose paso a través del sucio metabolismo de la ciudad.

\section{CONCLUSIÓN}

Los años nerviosos que preceden a la Primera Guerra Mundial son testigos de una intensa creatividad en todas las artes. El alma profética de los poetas detecta precozmente las grietas de un sismo que pronto sacudirá hasta lo irreconocible la faz de Europa. La gran ciudad, lugar de aluvión y laboratorio de formas e ideas, es algo insólito en el paisaje alemán; y los preclaros autores patricios de fin de siglo, principalmente Rilke, Hofmannsthal o George, al no admitirla como tema poético, dejan un extenso campo virgen a la imaginación plástica de generaciones subsiguientes. Las nuevas voces, que no son naturalistas ni esteticistas, ni están preocupadas por la reproducción fiel del paisaje urbano, se abren al libre juego de la fantasía, los vislumbres visionarios, el placer de lo grotesco, el sarcasmo blasé urbanita, la sátira radical y los ejercicios de asociación abstracta.

Las desinhibidas yuxtaposiciones que habían empezado a ensayar el cine, el cabaré, la prensa, el jazz y la pintura, se propagan también a la literatura. La poesía en alemán de estos años, aun bien anclada a los esquemas métricos tradicionales, ofrece - en contraste con su conservadurismo formal - una profunda serie de innovaciones en cuanto a temas, tono, figuras y organización. La producción de los autores seleccionados —Boldt, Hoddis, Zech, Lotz, Wegner, Petzold y Lichtenstein-, aunque de muy distinta estatura, ofrece trechos de enjundiosa belleza, que sorprenden aún por su desparpajo expresivo y sus ricas intuiciones. Las traducciones aquí realizadas intentan dar una idea de los tesoros literarios escondidos en estos años convulsos.

\section{OBRAS CITADAS}

Armas, Montserrat (2016), «El Café Josty», Bifurcaciones. Literatura, traducción, arte y filosofía. <https://montserratarmas.wordpress.com/2016/01/27/el-cafe-josty/>.

Barrento, João (2001), A Alma e o Caos. 100 poemas expresionistas, Lisboa, Relógio d'Água.

Becker, Sabina (1993), Urbanität und Moderne: Studien zur Grossstadtwahrnehmung in der deutschen Literatur, 1900-1930, St. Ingbert, W.J. Röhrig.

Boldt, Paul (1914), Junge Pferde! Junge Pferde!, Leipzig, Kurt Wolff.

Corbière, Tristan (1873), Les amours jaunes, Paris, Glady.

GHDI = Pettit, Richard, «Paul Boldt, "On the Terrace of Café Josty" (1912)», German History in Documents and Images, vol. 5. <http://germanhistorydocs.ghi-dc.org〉. 
Giese, Peter Christian (1992), Interpretationshilfen: Lyrik des Expressionismus, Stuttgart, Dresden, E. Klett Verlag für Wissen und Bildung.

Gilman, Sheldon, Robert Levine y Harry Radford (2000), The Prose and Verse of Alfred Lichtenstein, trad. Sheldon Gilman, Robert Levine y Harry Radford, Bloomington, Indiana, XLibris.

Grätz, Katharina (2019), «Schlote, Schlacken, Hochöfen. Josef Wincklers Eiserne Sonette», en Mario Gotterbarm, Stefan Knödler y Dietmar Till (eds.), Sonett-Gemeinschaften: Die soziale Referentialität des Sonetts, Leiden, Ferdinand Schöningh, pp. 237-256.

Kähler, Hermann (1986), Berlin, Asphalt und Licht: die grosse Stadt in der Literatur der Weimarer Republik, Berlín, Dietz.

Korber, Tessy (1998), Technik in der Literatur der frühen Moderne, Wiesbaden, DUV.

Krause, Frank (2006), Klangbewusster Expressionismus: moderne Techniken des rituellen Ausdrucks, Berlín, Weidler.

Krause, Frank (2015), Literarischer Expressionismus, Gotinga, V\&R unipress.

Lach-Newinsky, Peter (2010), «Alfred Lichtenstein, Four Poems». <https://peterlachnewinsky.wordpress.com/2010/09/01/alfred-lichtenstein-four-poems>.

Lichtenstein, Alfred (1962), Gesammelte Gedichte, ed. Klaus Kanzog, Zúrich, Arche.

Lotz, Ernst Wilhelm (1913), Und schöne Raubtierflecken..., Ein lyrisches Flugblatt, BerlínWilmersdorf, Alfred Richard Meyer Verlag.

Lotz, Ernst Wilhelm (1917), Wolkenüberflaggt (Der jüngste Tag, Band 36), Leipzig, Kurt Wolff Verlag.

Mattenklott, Gert y Gundel Mattenklott (1987), Berlin Transit: eine Stadt als Station, Reinbek, Rohwolt.

Modern, Rodolfo E. (1958), El expresionismo literario, Buenos Aires, Editorial Nova.

Müller, Dorit (2004), Gefährliche Fahrten: das Automobil in Literatur und Film um 1900, Würzburg, Königshausen \& Neumann.

Neumeyer, Harald (1999), Der Flaneur: Konzeptionen der Moderne, Würzburg, Königshausen $\&$ Neumann.

Payer, Peter (2018), Der Klang der Großstadt: Eine Geschichte des Hörens. Wien 1850-1914, Viena, Böhlau Verlag.

Petzold, Alfons (1919), Der Dombusch. Soziale Gedichte, Viena, Strache.

Piccoli, Héctor (2006), «Traducción. Paul Zech», Poesía de Rosario. Revista Internacional de Poesía, 15, s.p.

Porena, Ida (ed.) (1984), Alfred Lichtenstein: Storie di Kuno Kohn. Racconti e poesie, Milán, Adelphi.

Reina Palazón, José Luis (2004), Antología esencial de la poesía alemana, Madrid, Espasa Calpe.

Rohland de Langbehn, Régula, Carlos Lorenzo Langbehn y Pablo Gianera (1997), «Ocho poemas de Paul Zech, con su traducción al castellano», Inter Litteras: revista de la sección de literatura en lenguas extranjeras, 6, pp. 89-93.

Rothe, Wolfgang (ed.) (1981), Deutsche Großstadtlyrik vom Naturalismus bis zur Gegenwart, Stuttgart, Reclam.

Ruleman, William (2016), «William Ruleman - Poems and Translations». <https://thegalwayreview.com/2016/12/02/william-ruleman-poems-and-translations/>.

Ruleman, William (november 2017), «Five city poets from a century ago», Adelaide Literary Magazine, III (10). <https://adelaidemagazine.org/november2017.html>.

Scheiffele, Eberhard (2005), «Poèmes de Paul Boldt en traduction française par Eberhard Scheiffele». <http://www.paul-boldt.de/les-poemes-de-paul-boldt-en-traductionfrancaise-par-eberhard-scheiffele $>$.

Van Hoddis, Jakob (1958), Weltende. Gesammelte Dichtungen, ed. Paul Pörtner, Zúrich, Verlag der Arche, Peter Schifferli.

Versluys, Kristiaan (1987), The Poet in the City: Chapters in the Development of Urban Poetry in Europe and the United States, 1800-1930, Tubinga, Gunter Narr.

Vietta, Silvio (1992), Die Literarische Moderne. Eine problemgeschichtliche Darstellung der deutschen Literatur von Hölderlin bis Thomas Bernhard, Stuttgart, J. B. Metzler 
Wegner, Armin T. (1917), Das Antlitz der Städte, Berlín, Egon Fleischel \& Co.

Zawodny, Angelika (1999), "[...] erbau ich täglich euch den allerjüngsten Tag». Spuren der Apokalypse in expressionistischer Lyrik, Tesis doctoral, Universidad de Colonia.

Zech, Paul (noviembre 1913), «Zwei Wupperstädte», Der Sturm, 4 (184-185).

Zech, Paul (1914), Die Eiserne Brücke. Neue Gedichte, Leipzig, Weißen Bücher.

Zinecker, Rudolf (1934), Deutsche Grossstadtlyrik (1910-1930): Mit besonderer Berücksichtigung des Expressionismus 1910-1914, Praga, Gebrüder Stiepel. 